\title{
BUSINESS SIMULATION BEFORE AND AFTER ENTRE4FUTURE PROJECT: LESSONS LEARNED
}

\author{
Paulino Silva ${ }^{1}$, Rui Bertuzi ${ }^{2}$, Anabela Mesquita ${ }^{3}$ \\ ${ }^{1}$ CICE \& CECEJ - ISCAP / IPP (PORTUGAL) \\ ${ }^{2}$ CICE - ISCAP / IPP (PORTUGAL) \\ ${ }^{3}$ CICE - ISCAP / IPP \& Algoritmi RC (PORTUGAL)
}

\begin{abstract}
This paper presents the lessons learned after the introduction of Business Simulation (BS) courses at ISCAP / IPP as a result of the participation in the international project "Entre4Future - Simulation for Entrepreneurship". Besides the exchange of professional experience among teachers, researchers and students, Entre4future Project intends to develop outputs, such as teaching methodologies and innovative contents to prepare young people to be entrepreneurs. Partners from different levels of education (vocational schools, higher education institutions) and from the business world (Chambers of Commerce and Industry) were selected to be part of the project. BS courses are part of the Accounting and Administration degree since 2003 and methodologies used are in some way innovative, as the aim is to provide the students the possibility to work in a real (but simulated and risk free) business environment. Although some previous studies demonstrated the importance of BS for profession life of accounting and administration students, it was recognized that when it comes to develop entrepreneurial skills small gaps were identified. In order to overcome this problem and using the knowledge acquired with the Entre4future project, additional training was provided in order to prepare students in areas where they were not sufficiently prepared, using BS. The paper shows the very positive perception of students to this initiative and gives some clues to a possible inclusion of this new training in BS courses, which are part of the programme of studies of the Accounting and Administration degree.
\end{abstract}

Keywords: Business Simulation, Simulation for Entrepreneurship, Entrepreneurship, Innovative education, Teaching methodologies.

\section{INTRODUCTION}

Business Simulation (BS) is a curricular unit (CU) in the programme of studies of Accounting and Administration of the Accounting and Business School (Polytechnic Institute of Porto) in place for several years. At the beginning the $\mathrm{CU}$ was introduced in the Accounting and Administration degree in order to provide the access to the chamber of Portuguese certified accountants. The use of a learning by doing approach was very innovative at that time. In 2003, the year when BS was introduced, there were no Bologna Process implemented yet in Portuguese Higher Education institutions, which happened several years later, in 2007. The principles and characteristics of the Bologna Process were very similar to the ones used in BS [1].

As the time passed by the course was more and more valued by students and especially by former students. Some very interesting feedback was received by alumni that were working in management and accounting jobs, saying the experience they had in BS was very important for the performance of their jobs. In fact, BS helps students to develop competences, not only related with the accounting profession but also about general management and entrepreneurship.

In this line, when the Entre4future project proposal was being prepared to be submitted authors realized this was an excellent opportunity not only to share the BS experience with other colleagues in Europe, but also to improve the curricular unit by including other topics not so well developed, such as creativity and innovation. Creativity and innovation skills are considered fundamental for an entrepreneur and these were not sufficiently developed in BS.

During the international meeting of Entre4future in Portugal (May 2016), and after providing the partners of the project a BS experience in a real class with students, there was a very interesting question from one of the partners: "Your BS project is fantastic but you miss some skills for a today's entrepreneur. For example, where is creativity and innovation which are so important these days?" 